OPEN ACCESS

Edited by:

Michael Nevels,

University of Regensburg, Germany

Reviewed by:

Leonid Margolis,

National Institutes of Health, USA

Miriam Lichtner,

Sapienza - Università di Roma, Italy

*Correspondence:

Emily Adland,

Department of Paediatrics, Peter

Medawar Building for Pathogen

Research, University of Oxford, South

Parks Road, OXford OX1 3SY, UK

emily.adland@paediatrics.ox.ac.uk

Specialty section:

This article was submitted to

Virology,

a section of the journal

Frontiers in Microbiology

Received: 09 June 2015 Accepted: 08 September 2015

Published: 24 September 2015

Citation:

Adland E, Klenerman P, Goulder P and Matthews PC (2015) Ongoing burden

of disease and mortality from

HIV/CMV coinfection in Africa in the

antiretroviral therapy era.

Front. Microbiol. 6:1016.

doi: 10.3389/fmicb.2015.01016

\section{Ongoing burden of disease and mortality from HIV/CMV coinfection in Africa in the antiretroviral therapy era}

\author{
Emily Adland ${ }^{1 *}$, Paul Klenerman ${ }^{2,3,4}$, Philip Goulder ${ }^{1,5}$ and Philippa C. Matthews ${ }^{2,3}$ \\ ${ }^{1}$ Department of Paediatrics, Peter Medawar Building for Pathogen Research, University of Oxford, Oxford, UK, ${ }^{2}$ Nuffield \\ Department of Medicine, Peter Medawar Building for Pathogen Research, University of Oxford, Oxford, UK, ${ }^{3}$ Department of \\ Infectious Diseases and Microbiology, John Radcliffe Hospital, Oxford University Hospitals NHS Trust, Oxford, UK, ${ }^{4}$ National \\ Institute for Health Research Biomedical Research Centre, Oxford, UK, ${ }^{5}$ HIV Pathogenesis Programme, Doris Duke Medical \\ Research Institute, University of KwaZulu-Natal, Durban, South Africa
}

Human Cytomegalovirus (CMV) is a well-recognized pathogen in the context of HIV infection, but since the roll out of ART, clinical and scientific interest in the problem of HIV/CMV coinfection has diminished. However, CMV remains a significant cofactor in HIV disease, with an influence on HIV acquisition, disease progression, morbidity, and mortality. Disease manifestations may be a result of direct interplay between the two viruses, or may arise as a secondary consequence of immune dysregulation and systemic inflammation. The problem is most relevant when the rates of coinfection are high, most notably in sub-Saharan Africa, and in children at risk of acquiring both infections early in life. Understanding the interplay between these viruses and developing strategies to diagnose, treat and prevent CMV should be a priority.

Keywords: HIV-1, CMV, coinfection, sub-Saharan Africa, pediatric infectious diseases, immune activation, antiretroviral therapy

\section{Introduction}

Human cytomegalovirus (CMV) is a ubiquitous $\beta$-herpesvirus, also known as Human Herpes Virus 5 (HHV5). It is the largest of the human herpesviruses with a $230 \mathrm{~kb}$ genome encoding 165 genes. CMV is widely recognized as an opportunistic pathogen, and has a high profile as an agent of disease in immunocompromised patients; much of the recent research literature addresses infection in those undergoing solid organ and bone marrow transplantation (Crough and Khanna, 2009; Gracia-Ahufinger et al., 2015; Itzykson et al., 2015; Stevens et al., 2015).

CMV disease in the context of HIV is equally well-established, although interest in the manifestations of coinfection has substantially diminished in the ART era. However, the complex interplay between these two chronic viral infections continues to be potentially highly significant, both in adults and children, and particularly in certain vulnerable populations, including subSaharan Africa, where both CMV and HIV are endemic in neonates and children, leading to a risk of coinfection in utero and during the earliest days of life (King et al., 2013). There has recently been

Abbreviations: HIV, Human Immunodeficiency Virus (denotes HIV-1); CMV, Cytomegalovirus; HHV5, Human Herpes Virus-5; ART, Antiretroviral Therapy; MSM, Men who have Sex with Men; HEU, HIV Exposed Uninfected; AICD, Activation Induced Cell Death; PMTCT, Prevention of Mother-To-Child Transmission. 
a revival of interest in CMV as a cofactor for HIV infection and expert opinion has drawn attention to this somewhat neglected topic in the literature (Emery, 2014).

We have therefore set out to review the epidemiology, immunology and clinical impact of CMV infection in the setting of co-infection with HIV, focusing particularly on it's impact in southern African populations-especially in children who are at high risk of acquiring both infections within the first year of life.

We performed a PubMed search to identify reports of HIV/CMV coinfection, particularly representing studies conducted in sub-Saharan Africa. We have restricted references to focus primarily on publications from within the last 10 years. As there is a paucity of data from Africa, we have also cited studies of other populations where they raise points that are of particular relevance.

\section{Epidemiology of CMV Mono- and Co-infection}

\section{Transmission and Risk Factors}

CMV can be transmitted via saliva, sexual contact, placental transfer, breastfeeding, blood transfusion, and transplantation of solid-organs or haematopoietic stem cells. In African studies, factors including poor nutrition and low weight (Tembo et al., 2015), crowded living conditions (Alao et al., 2009) and other herpes virus coinfections (Schaftenaar et al., 2014) are associated with increased CMV seroprevalence. Maternal CMV viraemia during pregnancy is a risk factor for perinatal CMV transmission (Munro et al., 2005).

In the Western world, the rate of CMV seropositivity is much higher among adults with risk factors for acquisition of HIV infection, for example MSM (Gianella et al., 2015), than in the general population. Likewise, in a West African cohort, increased CMV seropositivity has also been demonstrated in HIV-positive individuals compared to HIV-uninfected controls (Compston et al., 2009). These observations all suggest shared risk factors for acquisition of the two viruses (e.g., lifestyle, behavior, demographics) as well as raising the possibility that HIV infection may be a direct risk factor for CMV acquisition in adults. The reciprocal scenario may also apply, as recent data from Africa suggest that CMV infection may be a risk factor for HIV transmission; a study in KwaZulu-Natal found an independent association between CMV in breast milk and postnatal mother-to-child transmission of HIV (Viljoen et al., 2015).

\section{Seroprevalence in Adults and Children}

In the USA, Australia and Europe, CMV seroprevalence among adults is variable, estimated at between 36 and $77 \%$; in contrast, CMV is highly endemic in developing countries and in particular in sub-Saharan Africa, with a seropositivity rate that often approaches $100 \%$ in adults (Chakraborty et al., 2003; Schlesinger et al., 2005; Miles et al., 2007, 2008; van der Sande et al., 2007; Zhang et al., 2007; Dar et al., 2008; Alao et al., 2009; Compston et al., 2009; Micol et al., 2009; Pass et al., 2009; Cannon et al., 2010; Chakravarti et al., 2010; Fielding et al., 2011; Brantsæter et al., 2012; Hsiao et al., 2013;
Manicklal et al., 2013, 2014; Gumbo et al., 2014; Lanzieri et al., 2014; Mwaanza et al., 2014; Schaftenaar et al., 2014; Lichtner et al., 2015; Tembo et al., 2015; Viljoen et al., 2015) (Figure 1).

Congenital CMV accounts for a significant burden of morbidity, including sensorineural deafness, developmental delay, and intrauterine growth retardation. This is estimated to affect $0.2-3 \%$ of live births in Western Europe and up to $14 \%$ in developing countries (Schlesinger et al., 2005; Zhang et al., 2007; Cannon et al., 2010; Manicklal et al., 2013, 2014; Gumbo et al., 2014; Mwaanza et al., 2014). The prevalence of congenital CMV in different African populations is likely to vary; data are sparse but studies range from rates of $2.9 \%$ in South Africa (Manicklal et al., 2014), to 3.8\% in Zambia (Mwaanza et al., 2014), and 5.4\% in the Gambia (van der Sande et al., 2007). Subsequently, almost two thirds of infants in African studies show serological evidence of infection by 3 months of age and $85 \%$ are infected by a year (Miles et al., 2007; Gumbo et al., 2014). By adolescence, CMV IgG is thought to be virtually universal in sub-Saharan African populations (Chakraborty et al., 2003).

In resource-poor settings, a large proportion of children undergo simultaneous primary HIV and CMV infection (Miles et al., 2007; Slyker et al., 2009). Thus, among HIV-positive children in Africa, the majority are coinfected with CMV by their first birthday (Miles et al., 2008; Gumbo et al., 2014), and almost all are coinfected by the time they reach their teens (Chakraborty et al., 2003). The growing epidemic of coinfected adolescents may have significant clinical impact in these populations. In comparison, a study from North America reports a lower-although still substantial-rate of early coinfections, finding that $40-50 \%$ of HIV/CMV-coinfected children had acquired CMV before their first birthday (Kovacs et al., 1999).

CMV infection is more common in neonates with HIV infection compared with HEU infants; to date it has not been possible to determine what proportion of CMV infections were acquired in utero (Tembo et al., 2015). Several mechanisms may explain the increased prevalence of CMV in HIV-infected neonates; first, HIV-infected mothers who transmitted HIV in utero would be expected to be more immunosuppressed and therefore at increased risk of reactivating and transmitting CMV. Second, immunosuppression associated with fetal HIV infection may result in higher risk of CMV acquisition in utero. Alternatively, fetal CMV coinfection may facilitate HIV acquisition in utero (Slyker et al., 2009).

\section{Immune Control of CMV}

CMV immune control is multifactorial and there is evidence to suggest that CD8+ and CD4+ T cells, NK cells and antibodymediated immunity all play a role in containment. We have summarized the key elements in Figure 2, highlighting the complex interplay of multiple limbs of the immune system in containing CMV infection. When any component of this immune control is aberrant, there is an increased risk of disease 


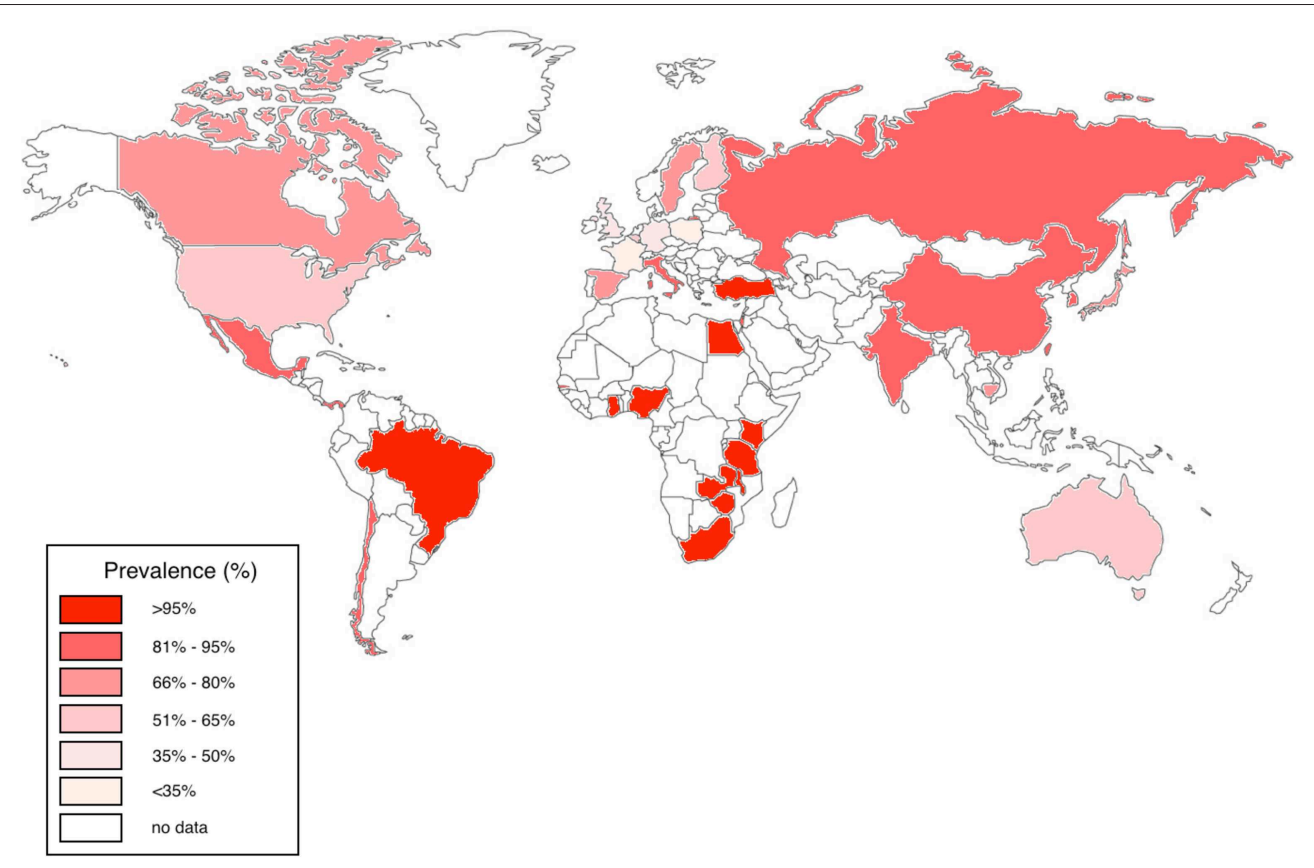

FIGURE 1 | Worldwide CMV seroprevalence rates in adults. We have represented studies of adults aged 16-50 years published between 2005 and 2015 from Australia, Belgium, Brazil, Canada, Cambodia, Chile, China, Finland, France, Gambia, Germany, Ghana, India, Israel, Italy, Japan, Kenya, Mexico, Nigeria, Panama, South Africa, Spain, Sweden, Taiwan, Tanzania, Turkey, UK, USA, Zambia, and Zimbabwe (Chakraborty et al., 2003; Schlesinger et al., 2005; Miles et al., 2007, 2008; van der Sande et al., 2007; Zhang et al., 2007; Dar et al., 2008; Alao et al., 2009; Compston et al., 2009; Micol et al., 2009; Pass et al., 2009; Cannon et al., 2010; Chakravarti et al., 2010; Fielding et al., 2011; Brantsæter et al., 2012; Hsiao et al., 2013; Manicklal et al., 2013, 2014; Gumbo et al., 2014; Lanzieri et al., 2014; Mwaanza et al., 2014; Schaftenaar et al., 2014; Lichtner et al., 2015; Tembo et al., 2015; Viljoen et al., 2015).

either due to primary CMV or reactivation of latent CMV, both of which can lead to disease manifestations.

There is also evidence that CMV can impact on immunological development, both in children and in adults (Ben-Smith et al., 2008; Miles et al., 2008a,b). In one study of adolescents, the CMV-positive group (mostly from Malawi) had fewer naïve CD4+ and CD8+ T cells and more differentiated memory $\mathrm{T}$ cells than CMV-negative subjects (Ben-Smith et al., 2008). This immunological phenotype is in keeping with that normally seen in older adults and equates with less robust $\mathrm{T}$ cell responses to new pathogens. Interestingly, CMV infection may also have a beneficial effect on immune responses to other pathogens: there are data from the Gambia suggesting that CMV infection can promote active T-cell responses in infancy, leading to more robust $\mathrm{CD} 8+$ responses to measles immunization and to staphylococcal enterotoxins (Miles et al., 2008).

\section{Immunopathology of HIV/CMV Coinfection}

One African study reports a strong correlation between peak HIV viral load and peak CMV viral load (Slyker et al., 2009). There are several possible explanations for this. First, a direct influence may operate between HIV and CMV viraemia, although it is impossible to infer causation or the direction of such a relationship: whether symptomatic CMV disease is a cause or effect of high HIV-p24 antigen concentration is not known. Second, it is also likely that there is an indirect effect, whereby systemic inflammation fuels the replication of both viruses (Griffiths, 2006). Finally, similar host factors may affect the containment of both viruses. Several direct influences of CMV on HIV have been proposed, as follows:

\section{Increased Infection of CD4+ T Cells by HIV}

In vitro investigations suggest a synergistic effect of $\mathrm{CMV}$ and HIV in infecting CD4 $+\mathrm{T}$ cells and mediating immune suppression. CMV does not itself infect CD4+ T cells, but may enhance the uptake of HIV into these cells by several different mechanisms:

- The US28 gene of CMV encodes a chemokine receptor that can act as a substitute for the HIV receptor CCR5, so facilitating entry of HIV into CD4+ T cells (Pleskoff et al., 1997).

- CMV encodes a molecule which can act as an alternative receptor for HIV; HIV coated in non-neutralizing antibodies can gain access to fibroblasts via this CMV-encoded $\mathrm{Fc}$ receptor (McKeating et al., 1990). However, the significance of this process is uncertain, as fibroblasts do not support productive HIV infection.

- Active CMV infection can alter the cell tropism of HIV in dually infected individuals by facilitating HIV DNA entry into ordinarily non-permissive human fibroblasts (Margalith et al., 1995). For example, activation induced by CMV upregulates expression of CCR5 in CD4+ T central memory cells and facilitates in utero transmission of HIV (Johnson et al., 2014). 


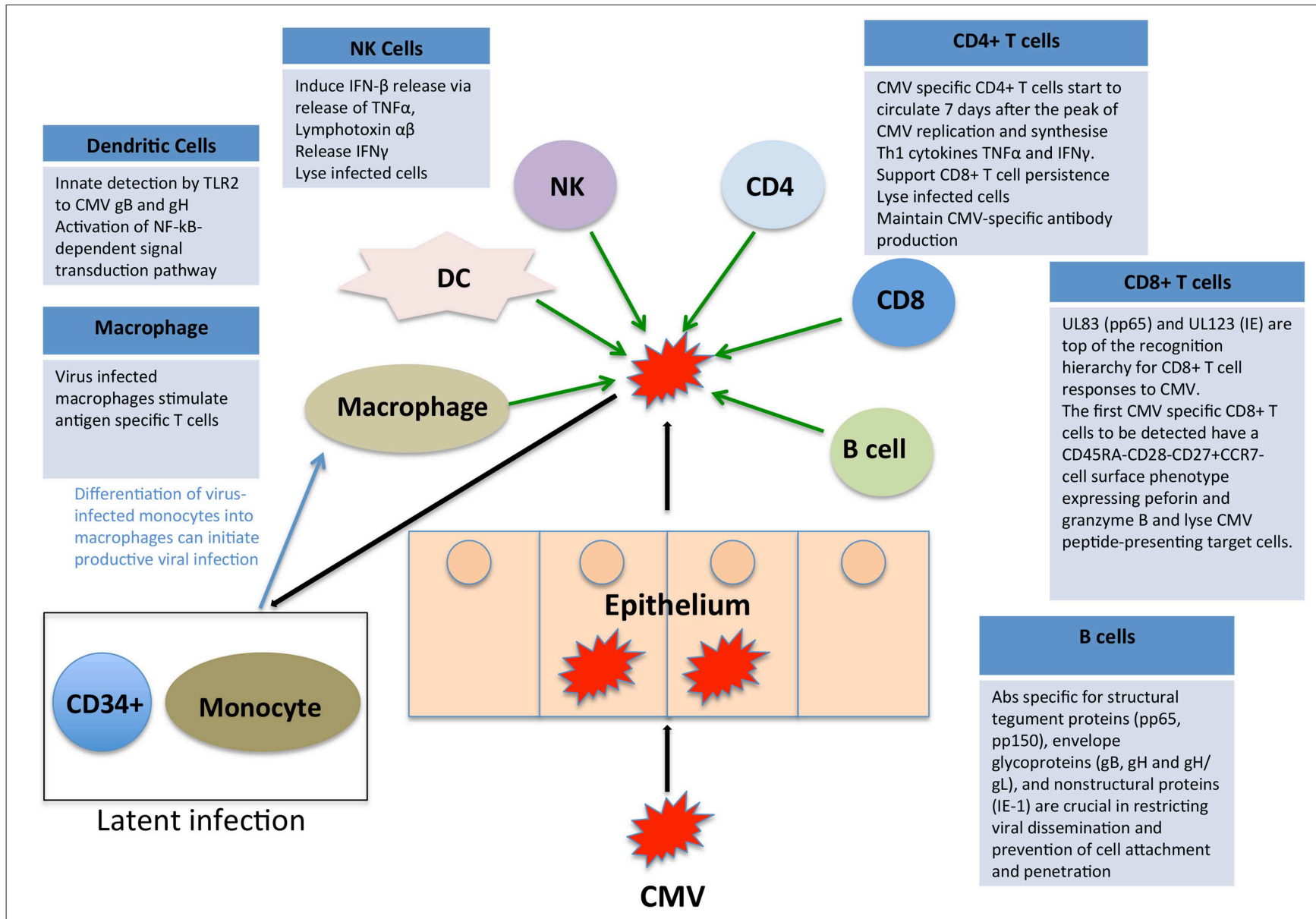

FIGURE 2 | Impact of the immune system on CMV. CMV immune control is reliant on both the innate and adaptive arms of the immune system. We have here summarized the key elements, highlighting the complex interplay of multiple limbs of the immune system in containing CMV infection.

\section{Re-activation of Latent HIV}

CMV may activate latent proviral HIV DNA by several different mechanisms at the molecular level, briefly outlined below, and also explored by other reviews (Griffiths, 2006):

- The CMV IE-2 gene can augment HIV gene expression within the same cell (Davis et al., 1987).

- CMV infection causes release of cytokines from a bystander cell, activating latent HIV provirus through signal transduction (Clouse et al., 1989).

- Exposure to CMV antigen from a bystander cell could promote activation of latent HIV in a T memory cell whose cognate antigen receptor is CMV-specific (Peterson et al., 1992).

- Intermediate and early CMV genes can increase HIV expression by induction of NF-kappa B transcription factor, activating transcription from a stably expressed HIV-1 long terminal repeat (Davis et al., 1987).

- CMV upregulates cytokines including IL-2, IL-6, and TNFa that may contribute to inducing HIV replication (Osborn et al., 1989).

\section{Cellular Immune Activation and Apoptosis}

Cellular activation caused by CMV contributes to HIV pathogenesis by depletion of $\mathrm{T}$ cells via apoptosis induced cell death (AICD) (Slyker et al., 2012). Apoptosis is a hallmark of $\mathrm{HIV}$ infection and increased AICD is thought to contribute to the gradual loss of CD4+ helper cells during progression toward AIDS. The CD95/APO-1/Fas receptor/ligand system is critically involved in induction of apoptosis (Böhler et al., 2001; Cummins and Badley, 2010). Dysregulation of this system contributes to increased AICD of T cells in HIV infection and is associated with disease progression (Sloand et al., 1997; Silvestri et al., 1998; Böhler et al., 2001; Cummins and Badley, 2010).

In a cohort of Kenyan HIV-infected infants, the frequencies of activated (CD38+ HLA-DR+) and apoptosis vulnerable (CD95+Bcl-2-) CD4+ and CD8+ T cells increased substantially during acute CMV infection (Slyker et al., 2012). Similar observations were made in HEU infants (Slyker et al., 2012). These data support the hypothesis that CMV-induced $\mathrm{T}$ cell activation and Fas-mediated apoptosis potentially contribute to the increased HIV disease progression observed particularly in CMV coinfected infants (Kovacs et al., 1999). 


\section{Clinical Consequences of CMV/HIV Coinfection}

In the pre-ART era, end-organ disease caused by CMV was the most common presentation of HIV infection, particularly retinitis at absolute $\mathrm{CD} 4+\mathrm{T}$ cell counts $<50 / \mathrm{mm} 3$. These manifestations are now much less frequent as ART successfully preserves CD4 counts, but the more subtle immune dysregulation associated with HIV-CMV coinfection is now recognized as a cause for concern. There is good evidence to support the relationship between CMV infection and increased disease progression and mortality in HIV infection (Table 1). However, it remains unknown whether acquisition or reactivation of CMV infection are markers of the immune dysfunction associated with HIV replication, or whether CMV infection itself is a co-factor that promotes HIV progression. These potential pathways are summarized by Figure 3, highlighting the cross-talk between CMV and the immune system.

In Western settings, active CMV disease in HIV-infected patients has significantly declined in the ART era (Chakravarti et al., 2010), perhaps providing false reassurance that CMV is not a relevant co-pathogen. However, in resource poor settings, including many parts of sub-Saharan Africa, there are few data to inform our understanding of clinical interplay between CMV and HIV. Furthermore, there is increasing evidence to suggest that CMV remains a relevant co-factor in disease progression in individuals with HIV, irrespective of ART (Riou et al., 2015), highlighted by the following three points:

\section{Accelerated Rate of Progression of HIV}

Progression to an AIDS-defining event has been significantly and independently associated not only with HIV RNA viral load and CD4+ $\mathrm{T}$ cell count, but also with CMV DNA (Erice et al., 2003; Fielding et al., 2011). In a population of HIV-infected hemophiliacs, coinfection with CMV adversely influenced the course of the disease; in particular, the ageadjusted relative risk of developing AIDS in CMV-seropositive patients was 2.5 times that in CMV seronegatives (Webster et al., 1989). Conversely, ART dramatically reduces HIV replication, so delaying the development of immunocompromise and disease. Immune reconstitution secondary to ART results in a significant and progressive decline in blood CMV viraemia even in the absence of specific anti-CMV therapy (Connick, 2001).

\section{Mortality}

In studies conducted in developed countries, detectable CMV DNA in plasma (Wohl et al., 2005) or in whole blood (Deayton et al., 2004; Reus et al., 2004) have been shown to be independent predictors of death even after adjusting for HIV RNA level or CD4+ T cell count. Strikingly, a recent study of HIV-positive adults in rural Tanzania that used dried blood spots to detect CMV viraemia found a hazard ratio of 5 for mortality in the presence of CMV (Brantsæter et al., 2012).
TABLE 1 | Association between CMV infection and disease progression and mortality in HIV infection in African children.

\begin{tabular}{|c|c|c|c|c|}
\hline Author & $\begin{array}{l}\text { Publication } \\
\text { Year }\end{array}$ & $\begin{array}{l}\text { Study } \\
\text { Location }\end{array}$ & $\begin{array}{l}\text { Population } \\
\text { Studied }\end{array}$ & Findings \\
\hline Vilioen & 2015 & $\begin{array}{l}\text { South } \\
\text { Africa }\end{array}$ & $\begin{array}{l}124 \\
\text { HIV-infected } \\
\text { mothers and } \\
\text { their babies }\end{array}$ & $\begin{array}{l}\mathrm{CMV} \text { is associated with } \\
\text { increased HIV shedding } \\
\text { in breast milk }\end{array}$ \\
\hline Gumbo & 2014 & Zimbabwe & $\begin{array}{l}257 \\
\text { ART-naiive } \\
\text { HIV-positive } \\
\text { infants }\end{array}$ & $\begin{array}{l}79 \% \text { CMV IgG positive } \\
\text { by age } 6 \text { weeks. No } \\
\text { increase in mortality } \\
\text { associated with CMV }\end{array}$ \\
\hline Tembo & 2015 & Zambia & $\begin{array}{l}303 \text { pediatric } \\
\text { inpatients, } \\
\text { age } 3 \text { weeks } \\
\text { to } 2 \text { years }\end{array}$ & $\begin{array}{l}\text { CMV viraemia in } 41 \% \text {, } \\
\text { associated with being } \\
\text { underweight, } \\
\text { HIV-positive, or } \\
\text { suspected meningitis }\end{array}$ \\
\hline Schaftenaar & 2014 & $\begin{array}{l}\text { South } \\
\text { Africa }\end{array}$ & $\begin{array}{l}405 \\
\text { ART-naïve } \\
\text { HIV-positive } \\
\text { children }\end{array}$ & $\begin{array}{l}\text { CMV IgG in } 100 \% \text {, } \\
\text { higher titres associated } \\
\text { with lower CD4+ T cell } \\
\text { count }\end{array}$ \\
\hline Manicklal & 2014 & $\begin{array}{l}\text { South } \\
\text { Africa }\end{array}$ & $\begin{array}{l}748 \text { neonates } \\
\text { born to } \\
\text { HIV-infected } \\
\text { mothers }\end{array}$ & $\begin{array}{l}\text { Congenital CMV in } \\
2.9 \% \text {, associated with } \\
\text { maternal CD4 count } \\
<200 \text { cells } / \mathrm{mm} 3\end{array}$ \\
\hline Mwaanza & 2014 & Zambia & 395 neonates & $\begin{array}{l}\text { Congenital CMV in } \\
3.8 \% \text {, maternal HIV } \\
\text { associated with } \\
\text { increased congenital } \\
\text { CMV infection }\end{array}$ \\
\hline Hsiao & 2013 & $\begin{array}{l}\text { South } \\
\text { Africa }\end{array}$ & $\begin{array}{l}425 \text { HIV } \\
\text { exposed } \\
\text { infants }\end{array}$ & $\begin{array}{l}\mathrm{CMV} \text { viraemia is } \\
\text { associated with } \\
\text { pneumonia in HIV } \\
\text { exposed infants }\end{array}$ \\
\hline Zampoli & 2011 & $\begin{array}{l}\text { South } \\
\text { Africa }\end{array}$ & $\begin{array}{l}202 \text { children } \\
\text { with } \\
\text { suspected } \\
\text { PCP }\end{array}$ & $\begin{array}{l}\text { CMV associated } \\
\text { pneumonia more } \\
\text { common in HIV } \\
\text { infected children }\end{array}$ \\
\hline Goussard & 2010 & $\begin{array}{l}\text { South } \\
\text { Africa }\end{array}$ & $\begin{array}{l}25 \\
\text { HIV-positive } \\
\text { children with } \\
\text { suspected } \\
\text { PJP }\end{array}$ & $\begin{array}{l}\text { CMV most likely cause } \\
\text { of pneumonia and is } \\
\text { associated with low } \\
\text { CD4 counts and } \\
\text { mortality }\end{array}$ \\
\hline Slyker & 2009 & Kenya & $\begin{array}{l}64 \text { infants } \\
\text { born to } \\
\text { HIV-positive } \\
\text { mothers }\end{array}$ & $\begin{array}{l}\text { Maternal CMV } \\
\text { DNAemia is a } \\
\text { significant factor for } \\
\text { mortality in HIV infected } \\
\text { infants }\end{array}$ \\
\hline Roxby & 2014 & Kenya & $\begin{array}{l}141 \text { infants } \\
\text { born to } \\
\text { HIV-positive } \\
\text { mothers }\end{array}$ & $\begin{array}{l}66 \% \text { acquired CMV by } \\
1 \text { year of age }\end{array}$ \\
\hline Slyker & 2012 & Kenya & $\begin{array}{l}474 \text { infants } \\
\text { born to } \\
\text { HIV-positive } \\
\text { mothers }\end{array}$ & $\begin{array}{l}\text { CMV induced T cell } \\
\text { activation contributes } \\
\text { to rapid disease } \\
\text { progression in } \\
\text { coinfected infants }\end{array}$ \\
\hline
\end{tabular}

The studies summarized are conducted solely in African children and published between 2009 and 2015.

A recent large $(n>6,000)$ study of HIV infected individuals in Italy, with high CMV seroprevalence (83.8\%), demonstrated an association between CMV IgG and time to a severe non-AIDS 


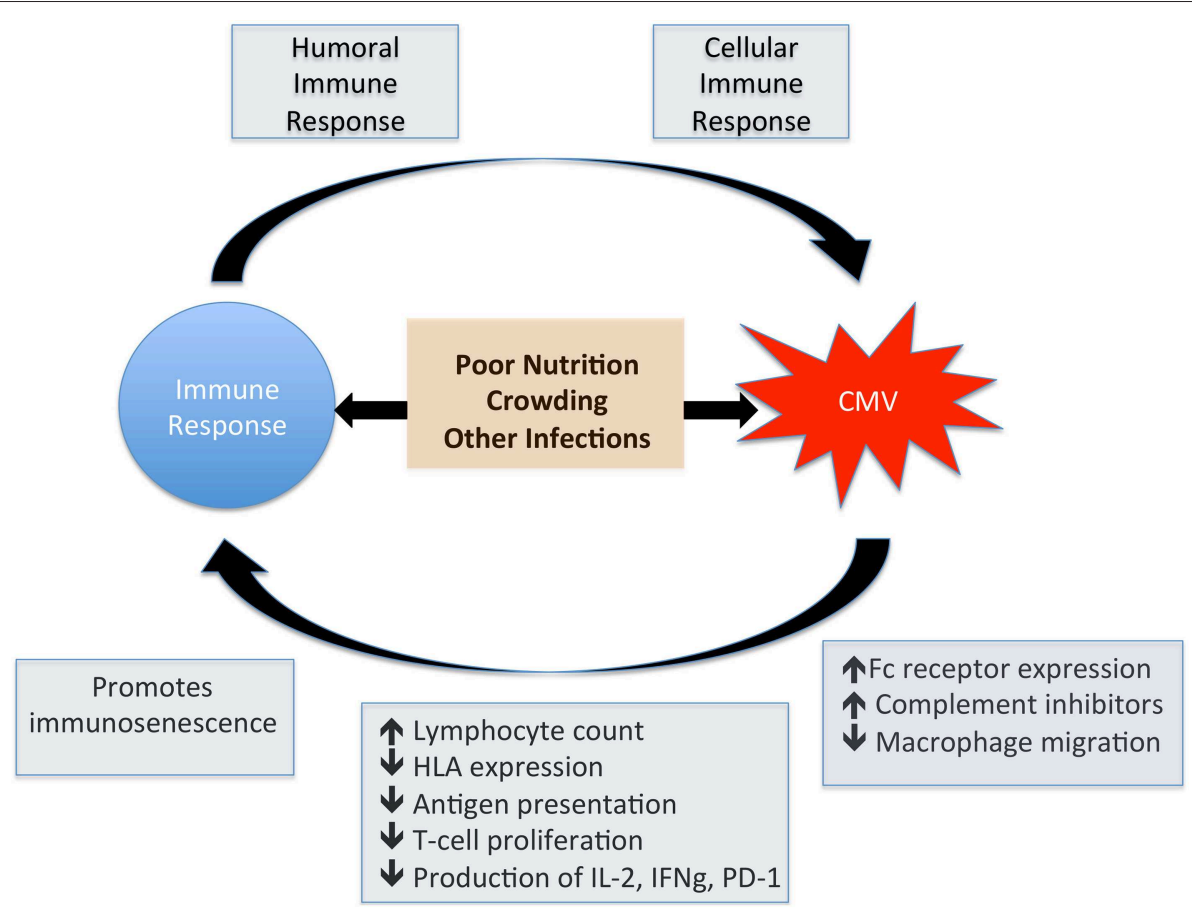

FIGURE 3 | Impact of CMV on the immune system. This figure shows the potential for bi-directional interplay between CMV and the immune response. CMV induces a robust humoral and cellular immune response whilst at the same time has a direct influence on normal immune function. Factors such as poor nutrition and low weight, crowded living conditions and other herpes virus coinfections also have an impact on immune function and are associated with increased CMV seroprevalence.

event such as the incidence of cardio/cerebro-vascular disease or non-AIDS related death (Lichtner et al., 2015). This study importantly demonstrates the potential for an enhanced disease burden associated with CMV in HIV-infected individuals, in whom coinfection does not necessarily result in AIDSdefining events or well-recognized CMV end-organ disease such as retinitis, but instead a more subtle interplay leads to pathology resulting from systemic inflammation and immune dysregulation. Similarly, other studies report an influence of CMV in driving early aging (e.g., decline in physical function) in HIV-infected adults (Erlandson et al., 2015).

\section{Pediatric HIV/CMV Coinfection}

As CMV presents a significant risk factor for HIV disease progression, its impact is likely to be particularly important in children in settings where both viruses are commonly acquired in infancy; several studies document the relationship between CMV coinfection and accelerated HIV progression and increased mortality in children (Kovacs et al., 1999; Goussard et al., 2010; Schaftenaar et al., 2014). In Kenya, detection of maternal CMV DNA in the blood near the time of delivery was associated with three to four-fold increased mortality in HIVinfected infants (Slyker et al., 2009). Strikingly, this relationship remained significant even after controlling for other strong predictors of infant mortality including maternal CD4+ T cell count, infant CD4+ $\mathrm{T}$ cell percentage, HIV RNA viral load and maternal death. Studies in HIV infected infants and HIV exposed uninfected infants also link early CMV acquisition with growth delay and cognitive impairment (Roxby et al., 2014).

$\mathrm{CD} 8+\mathrm{T}$ cell activation has been shown to accompany acute CMV infection in healthy Gambian infants (Miles et al., 2007); since this activation is a strong predictor of HIV disease progression, the acquisition of CMV during primary HIV infection may accelerate infant HIV progression. Again, there is evidence for a reciprocal impact of HIV on CMV, whereby $\mathrm{HIV}$ is associated with altered kinetics of CMV replication; specifically, CMV levels peaked at higher levels and tended to decline more slowly in HIV-infected infants (Slyker et al., 2009). Persistent detection of CMV DNA is common in both HIV infected and HEU infants in the 7-12 month post-infection period, suggesting incomplete containment of CMV replication in both these groups of children.

Taken together, these studies suggest that CMV remains a potentially significant pathogen, independently associated with worse outcomes in individuals with HIV, even in the setting of ART. Insight into the epidemiology, pathogenesis, and clinical impact of CMV is currently a neglected component of our understanding of the AIDS epidemic. Crucially, developing insights into the role of CMV in HIV disease could allow interventions including vaccination or anti-viral therapy for at-risk individuals.

As ART becomes more widely accessible to this population for both PMTCT and treatment, it will be important to determine the impact of maternal and infant ART on CMV epidemiology and pathogenesis. 


\section{Treatment and Prevention of CMV}

CMV disease responds to treatment with a variety of antiviral agents including ganciclovir, valganciclovir, cidofovir, and foscarnet. Access to appropriate diagnosis followed by anti-viral therapy is difficult in resource-constrained settings, although there is some precedent for CMV therapy in patients with CMV viraemia $>1000$ copies $/ \mathrm{ml}$ (Mayaphi et al., 2014), and therapy is clearly advocated for those in whom invasive end-organ disease is suspected or confirmed.

As access to both diagnosis and therapy for CMV disease may be restricted in resource-limited settings, a preventive vaccine is the most robust future strategy to reduce CMV-related morbidity and mortality. Two strategies have been employed to develop CMV vaccines. The first vaccine is live attenuated Towne virus; this has shown weak protection in a human challenge study (Plotkin et al., 1989) but failed to provide protection against infection in CMV seronegative women of childbearing age in an efficacy study (Adler et al., 1995). The second approach is an antigen based approach using recombinant gB/MF59 which showed more promise with $\sim 50 \%$ efficacy against CMV infection in a Phase II trial in seronegative women (Pass et al., 2009 ) and $\sim 50 \%$ efficacy in controlling viraemia in seronegative recipients of sero-positive organ transplants ("R-D+") (Griffiths et al., 2011).

Notably, vaccine trials have only been conducted in the western world but these have resulted in limited success (Wang and $\mathrm{Fu}, 2014)$. An effective CMV vaccine for prevention of congenital CMV infection is an increasing priority for the West (Arvin et al., 2004), but the effects of a vaccine could also be far-reaching in developing countries, particularly in populations coinfected with HIV.

\section{References}

Adler, S. P., Starr, S. E., Plotkin, S. A., Hempfling, S. H., Buis, J., Manning, M. L., et al. (1995). Immunity induced by primary human cytomegalovirus infection protects against secondary infection among women of childbearing age. J. Infect. Dis. 171, 26-32. doi: 10.1093/infdis/171.1.26

Alao, O. O., Mamman, A., Araoye, M. O., and Joseph, E. (2009). Effect of demographic variables on cytomegalovirus antibody seropositivity among prospective blood donors in Jos, Nigeria. Niger. Postgrad. Med. J. 16, 139-142.

Arvin, A. M., Fast, P., Myers, M., Plotkin, S., and Rabinovich, R. (2004). Vaccine development to prevent cytomegalovirus disease: report from the National Vaccine Advisory Committee. Clin. Infect. Dis. 39, 233-239. doi: $10.1086 / 421999$

Ben-Smith, A., Gorak-Stolinska, P., Floyd, S., Weir, R. E., Lalor, M. K., Mvula, $\mathrm{H}$., et al. (2008). Differences between naive and memory T cell phenotype in Malawian and UK adolescents: a role for Cytomegalovirus? BMC Infect. Dis. 8:139. doi: 10.1186/1471-2334-8-139

Böhler, T., Wintergerst, U., Linde, R., Belohradsky, B. H., and Debatin, K. M. (2001). CD95 (APO-1/Fas) expression on naive CD4(+) T cells increases with disease progression in HIV-infected children and adolescents: effect of highly active antiretroviral therapy (HAART). Pediatr. Res. 49, 101-110. doi: 10.1203/00006450-200101000-00021

Brantsæter, A. B., Johannessen, A., Holberg-Petersen, M., Sandvik, L., Naman, E., Kivuyo, S. L., et al. (2012). Cytomegalovirus viremia in dried blood spots is associated with an increased risk of death in HIV-infected patients:

\section{Conclusions}

A high incidence of coinfection occurring early in life, impaired CMV containment, persistent CMV DNA detection and a correlation between CMV and HIV peak viral loads suggest that CMV plays an important role in HIV in sub-Saharan Africa, as well as in other resource poor settings. Despite compelling evidence that these infections impact negatively on one another, this field is relatively neglected, particularly in some of the world's most vulnerable populations including neonates and developing world settings.

Although florid end-organ CMV disease may no longer be a substantial problem due to the increasing success of ART, there is growing evidence that its impact as a co-pathogen remains highly relevant. This may be mediated by immune activation and systemic inflammation driven by CMV, increasing the risks of HIV-related morbidity and mortality. There are also interesting data suggesting an effect of CMV on immune ontogeny, suggesting it has a role in determining the nature and efficacy of immune responses to a variety of other infections. This effect may be particularly pertinent in children.

Significant therapeutic benefits could potentially be derived from interventions to reduce the incidence of CMV infection, or to reduce the sequelae of chronic infection including disease reactivation and long-term immune activation.

\section{Funding}

PCM has salary support from the NIHR, and research grants from Oxford University Clinical Academic Graduate School (OUCAGS) and The John Fell Fund. PG is funded by the Wellcome Trust (WT104748MA) and PK is also funded by the Wellcome Trust (WT091663MA).

a cohort study from rural Tanzania. Int. J. Infect. Dis. 16, e879-e885. doi: 10.1016/j.ijid.2012.08.003

Cannon, M. J., Schmid, D. S., and Hyde, T. B. (2010). Review of cytomegalovirus seroprevalence and demographic characteristics associated with infection. Rev. Med. Virol. 20, 202-213. doi: 10.1002/rmv.655

Chakraborty, R., Rees, G., Bourboulia, D., Cross, A. M., Dixon, J. R., D’Agostino, A., et al. (2003). Viral coinfections among African children infected with human immunodeficiency virus type 1. Clin. Infect. Dis. 36, 922-924. doi: $10.1086 / 368207$

Chakravarti, A., Tewari, S., and Bhalla, P. (2010). Human cytomegalovirus infection among patients living with AIDS in a tertiary level hospital in India. J. Int. Assoc. Phys. AIDS Care (Chic) 9, 94-97. doi: 10.1177/1545109710366180

Clouse, K. A., Robbins, P. B., Fernie, B., Ostrove, J. M., and Fauci, A. S. (1989). Viral antigen stimulation of the production of human monokines capable of regulating HIV1 expression. J. Immunol. 143, 470-475.

Compston, L. I., Li, C., Sarkodie, F., Owusu-Ofori, S., Opare-Sem, O., and Allain, J. P. (2009). Prevalence of persistent and latent viruses in untreated patients infected with HIV-1 from Ghana, West Africa. J. Med. Virol. 81, 1860-1868. doi: $10.1002 / j m v .21614$

Connick, E. (2001). Immune reconstitution in HIV-1-infected individuals treated with potent antiretroviral therapy. J. Investig. Dermatol. Symp. Proc. 6, 212-218. doi: 10.1046/j.0022-202x.2001.00049.x

Crough, T., and Khanna, R. (2009). Immunobiology of human cytomegalovirus: from bench to bedside. Clin. Microbiol. Rev. 22, 76-98. doi: 10.1128/CMR.00034-08 
Cummins, N. W., and Badley, A. D. (2010). Mechanisms of HIV-associated lymphocyte apoptosis. Cell Death Dis. 1:e99. doi: 10.1038/cddis.2010.77

Dar, L., Pati, S. K., Patro, A. R., Deorari, A. K., Rai, S., Kant, S., et al. (2008). Congenital cytomegalovirus infection in a highly seropositive semiurban population in India. Pediatr. Infect. Dis. J. 27, 841-843. doi: 10.1097/INF.0b013e3181723d55

Davis, M. G., Kenney, S. C., Kamine, J., Pagano, J. S., and Huang, E. S. (1987). Immediate-early gene region of human cytomegalovirus trans-activates the promoter of human immunodeficiency virus. Proc. Natl. Acad. Sci. U.S.A. 84, 8642-8646. doi: 10.1073/pnas.84.23.8642

Deayton, J. R., Prof Sabin, C. A., Johnson, M. A., Emery, V. C., Wilson, P., Griffiths, P. D., et al. (2004). Importance of cytomegalovirus viraemia in risk of disease progression and death in HIV-infected patients receiving highly active antiretroviral therapy. Lancet 363, 2116-2121. doi: 10.1016/S01406736(04)16500-8

Emery, V. C. (2014). Restimulating interest in cytomegalovirus as a cofactor for HIV infection. J. Infect. Dis. 211, 169-171. doi: 10.1093/infdis/jiu419

Erice, A., Tierney, C., Hirsch, M., Caliendo, A. M., Weinberg, A., Kendall, M. A., et al. (2003). Cytomegalovirus (CMV) and human immunodeficiency virus (HIV) burden, CMV end-organ disease, and survival in subjects with advanced HIV infection (AIDS Clinical Trials Group Protocol 360). Clin. Infect. Dis. 37, 567-578. doi: 10.1086/375843

Erlandson, K. M., Allshouse, A. A., Rapaport, E., Palmer, B. E., Wilson, C. C., Weinberg, A., et al. (2015). Physical function impairment of older, HIV-infected adults is associated with cytomegalovirus immunoglobulin response. AIDS Res. Hum. Retroviruses 31, 905-912. doi: 10.1089/AID.2015.0085

Fielding, K., Koba, A., Grant, A. D., Charalambous, S., Day, J., Spak, C., et al. (2011). Cytomegalovirus viremia as a risk factor for mortality prior to antiretroviral therapy among HIV-infected gold miners in South Africa. PLoS ONE 6:e25571. doi: 10.1371/journal.pone.0025571

Gianella, S., Scheffler, K., Mehta, S. R., Little, S. J., Freitas, L., Morris, S. R., et al. (2015). Seminal shedding of CMV and HIV transmission among men who have sex with men. Int. J. Environ. Res. Public Health 12, 7585-7592. doi: 10.3390/ijerph120707585

Goussard, P., Kling, S., Gie, R. P., Nel, E. D., Heyns, L., Rossouw, G. J., et al. (2010). CMV pneumonia in HIV-infected ventilated infants. Pediatr. Pulmonol. 45, 650-655. doi: 10.1002/ppul.21228

Gracia-Ahufinger, I., Ferrando-Martínez, S., Montejo, M., Muñoz-Villanueva, M. C., Cantisán, S., Rivero, A., et al. (2015). Pre-transplant thymic function is associated with the risk of cytomegalovirus disease after solid organ transplantation. Clin. Microbiol. Infect. 21, 511.e1-511.e7. doi: 10.1016/j.cmi.2014.12.020

Griffiths, P. D., Stanton, A., McCarrell, E., Smith, C., Osman, M., Harber, M., et al. (2011). Cytomegalovirus glycoprotein-B vaccine with MF59 adjuvant in transplant recipients: a phase 2 randomised placebo-controlled trial. Lancet 377, 1256-1263. doi: 10.1016/S0140-6736(11)60136-0

Griffiths, P. D. (2006). CMV as a cofactor enhancing progression of AIDS. J. Clin. Virol. 35, 489-492. doi: 10.1016/j.jcv.2005.10.016

Gumbo, H., Chasekwa, B., Church, J. A., Ntozini, R., Mutasa, K., Humphrey, J. H., et al. (2014). Congenital and postnatal CMV and EBV acquisition in HIV-infected Zimbabwean infants. PLoS ONE 9:e114870. doi: 10.1371/journal.pone. 0114870

Hsiao, N. Y., Zampoli, M., Morrow, B., Zar, H. J., and Hardie, D. (2013). Cytomegalovirus viraemia in HIV exposed and infected infants: prevalence and clinical utility for diagnosing CMV pneumonia. J. Clin. Virol. 58, 74-78. doi: 10.1016/j.jcv.2013.05.002

Itzykson, R., Robin, M., Moins-Teisserenc, H., Delord, M., Busson, M., Xhaard, A., et al. (2015). Cytomegalovirus shapes long-term immune reconstitution after allogeneic stem cell transplantation. Haematologica 100, 114-123. doi: 10.3324/haematol.2014.113415

Johnson, E. L., Howard, C. L., Thurman, J., Pontiff, K., Johnson, E. S., Chakraborty, R., et al. (2014). Cytomegalovirus upregulates expression of CCR5 in central memory cord blood mononuclear cells, which may facilitate in utero HIV Type 1 transmission. J. Infect. Dis. 211, 187-196. doi: 10.1093/infdis/ jiu 424

King, C. C., Ellington, S. R., and Kourtis, A. P. (2013). The role of co-infections in mother-to-child transmission of HIV. Curr. HIV Res. 11, 10-23. doi: $10.2174 / 1570162 \times 11311010003$
Kovacs, A., Schluchter, M., Easley, K., Demmler, G., Shearer, W., La Russa, P., et al. (1999). Cytomegalovirus infection and HIV-1 disease progression in infants born to HIV-1-infected women. Pediatric pulmonary and cardiovascular complications of vertically transmitted HIV infection study group. N. Engl. J. Med. 341, 77-84. doi: 10.1056/NEJM199907083410203

Lanzieri, T. M., Dollard, S. C., Bialek, S. R., and Grosse, S. D. (2014). Systematic review of the birth prevalence of congenital cytomegalovirus infection in developing countries. Int. J. Infect. Dis. 22, 44-48. doi: 10.1016/j.ijid.2013.12.010

Lichtner, M., Cicconi, P., Vita, S., Cozzi-Lepri, A., Galli, M., Lo Caputo, S., et al. (2015). Cytomegalovirus coinfection is associated with an increased risk of severe non-AIDS-defining events in a large cohort of HIV-infected patients. J. Infect. Dis. 211, 178-186. doi: 10.1093/infdis/jiu417

Manicklal, S., Emery, V. C., Lazzarotto, T., Boppana, S. B., and Gupta, R. K. (2013). The "silent" global burden of congenital cytomegalovirus. Clin. Microbiol. Rev. 26, 86-102. doi: 10.1128/CMR.00062-12

Manicklal, S., van Niekerk, A. M., Kroon, S. M., Hutto, C., Novak, Z., Pati, S. K., et al. (2014). Birth prevalence of congenital cytomegalovirus among infants of HIV-infected women on prenatal antiretroviral prophylaxis in South Africa. Clin. Infect. Dis. 58, 1467-1472. doi: 10.1093/cid/ciu096

Margalith, M., D’Aquila, R. T., Manion, D. J., Basgoz, N., Bechtel, L. J., Smith, B. R., et al. (1995). HIV-1 DNA in fibroblast cultures infected with urine from HIV-seropositive cytomegalovirus (CMV) excretors. Arch. Virol. 140, 927-935.

Mayaphi, S. H., Brauer, M., Morobadi, D. M., Mazanderani, A. H., Mafuyeka, R. T., Olorunju, S. A., et al. (2014). Cytomegalovirus viral load kinetics in patients with HIV/AIDS admitted to a medical intensive care unit: a case for pre-emptive therapy. PLoS ONE 9:e93702. doi: 10.1371/journal.pone.0093702

McKeating, J. A., Griffiths, P. D., and Weiss, R. A. (1990). HIV susceptibility conferred to human fibroblasts by cytomegalovirus-induced $\mathrm{Fc}$ receptor. Nature 343, 659-661. doi: 10.1038/343659a0

Micol, R., Buchy, P., Guerrier, G., Duong, V., Ferradini, L., Dousset, J. P., et al. (2009). Prevalence, risk factors, and impact on outcome of cytomegalovirus replication in serum of Cambodian HIV-infected patients (2004-2007). J. Acquir. Immune Defic. Syndr. 51, 486-491. doi: 10.1097/QAI.0b013e3181a254c2

Miles, D. J., Sande, M., Kaye, S., Crozier, S., Ojuola, O., Palmero, M. S., et al. (2008b). CD4(+) T cell responses to cytomegalovirus in early life: a prospective birth cohort study. J. Infect. Dis. 197, 658-662. doi: 10.1086/527418

Miles, D. J., Sanneh, M., Holder, B., Crozier, S., Nyamweya, S., Touray, E. S., et al. (2008). Cytomegalovirus infection induces T-cell differentiation without impairing antigen-specific responses in Gambian infants. Immunology 124, 388-400. doi: 10.1111/j.1365-2567.2007.02787.x

Miles, D. J., van der Sande, M., Jeffries, D., Kaye, S., Ismaili, J., Ojuola, O., et al. (2007). Cytomegalovirus infection in Gambian infants leads to profound CD8 T-cell differentiation. J. Virol. 81, 5766-5776. doi: 10.1128/JVI.00052-07

Miles, D. J., van der Sande, M., Jeffries, D., Kaye, S., Ojuola, O., Sanneh, M., et al. (2008a). Maintenance of large subpopulations of differentiated CD8 T-cells two years after cytomegalovirus infection in Gambian infants. PLOS ONE 3:e2905. doi: 10.1371/journal.pone.0002905

Munro, S. C., Hall, B., Whybin, L. R., Leader, L., Robertson, P., Maine, G. T., et al. (2005). Diagnosis of and screening for cytomegalovirus infection in pregnant women. J. Clin. Microbiol. 43, 4713-4718. doi: 10.1128/JCM.43.9.47134718.2005

Mwaanza, N., Chilukutu, L., Tembo, J., Kabwe, M., Musonda, K., Kapasa, M., et al. (2014). High rates of congenital cytomegalovirus infection linked with maternal HIV infection among neonatal admissions at a large referral center in sub-Saharan Africa. Clin. Infect. Dis. 58, 728-735. doi: 10.1093/cid/cit766

Osborn, L., Kunkel, S., and Nabel, G. J. (1989). Tumor necrosis factor alpha and interleukin 1 stimulate the human immunodeficiency virus enhancer by activation of the nuclear factor kappa B. Proc. Natl. Acad. Sci. U.S.A. 86, 2336-2340. doi: 10.1073/pnas.86.7.2336

Pass, R. F., Zhang, C., Evans, A., Simpson, T., Andrews, W., Huang, M. L., et al. (2009). Vaccine prevention of maternal cytomegalovirus infection. N. Engl. J. Med. 360, 1191-1199. doi: 10.1056/NEJMoa0804749

Peterson, P. K., Gekker, G., Chao, C. C., Hu, S. X., Edelman, C., Balfour, H. H. Jr., et al. (1992). Human cytomegalovirus-stimulated peripheral blood mononuclear cells induce HIV-1 replication via a tumor necrosis factor-alphamediated mechanism. J. Clin. Invest. 89, 574-580. doi: 10.1172/JCI115623 
Pleskoff, O., Tréboute, C., Brelot, A., Heveker, N., Seman, M., Alizon, M., et al. (1997). Identification of a chemokine receptor encoded by human cytomegalovirus as a cofactor for HIV-1 entry. Science 276, 1874-1878. doi: $10.1126 /$ science. 276.5320 .1874

Plotkin, S. A., Starr, S. E., Friedman, H. M., Gönczöl, E., and Weibel, R. E. (1989). Protective effects of Towne cytomegalovirus vaccine against low-passage cytomegalovirus administered as a challenge. J. Infect. Dis. 159, 860-865. doi: 10.1093/infdis/159.5.860

Reus, S., Portilla, J., Gimeno, A., Sánchez-Payá, J., García-Henarejos, J. A., Martínez-Madrid, O., et al. (2004). [Predictors of progression and death in patients with advanced HIV infection in the era of highly active antiretroviral therapy]. Enferm. Infecc. Microbiol. Clin. 22, 142-149. doi: 10.1016/S0213005X(04)73054-2

Riou, C., Tanko, R. F., Soares, A. P., Masson, L., Werner, L., Garrett, N. J., et al. (2015). Restoration of CD4+ responses to Copathogens in HIV-infected individuals on antiretroviral therapy is dependent on $\mathrm{T}$ cell memory phenotype. J. Immunol. 195, 2273-2281. doi: 10.4049/jimmunol. 1500803

Roxby, A. C., Atkinson, C., Asbjornsdottir, K., Farquhar, C., Kiarie, J. N., Drake, A. L., et al. (2014). Maternal valacyclovir and infant cytomegalovirus acquisition: a randomized controlled trial among HIV-infected women. PLoS ONE 9:e87855. doi: 10.1371/journal.pone.0087855

Schaftenaar, E., Verjans, G. M., Getu, S., McIntyre, J. A., Struthers, H. E., Osterhaus, A. D., et al. (2014). High seroprevalence of human herpesviruses in HIVinfected individuals attending primary healthcare facilities in rural South Africa. PLoS ONE 9:e99243. doi: 10.1371/journal.pone.0099243

Schlesinger, Y., Reich, D., Eidelman, A. I., Schimmel, M. S., Hassanin, J., Miron, D., et al. (2005). Congenital cytomegalovirus infection in Israel: screening in different subpopulations. Isr. Med. Assoc. J. 7, 237-240.

Silvestri, G., Munoz-Calleja, C., Bagnarelli, P., Piedimonte, G., Clementi, M., Montroni, M., et al. (1998). Early increase of CD4+ CD45RA+ and CD4+ CD95- cells with conserved repertoire induced by anti-retroviral therapy in HIV-infected patients. Clin. Exp. Immunol. 111, 3-11. doi: 10.1046/j.13652249.1998.00464.x

Sloand, E. M., Young, N. S., Kumar, P., Weichold, F. F., Sato, T., Maciejewski, J. P., et al. (1997). Role of Fas ligand and receptor in the mechanism of T-cell depletion in acquired immunodeficiency syndrome: effect on CD4+ lymphocyte depletion and human immunodeficiency virus replication. Blood $89,1357-1363$.

Slyker, J. A., Lohman-Payne, B. L., Rowland-Jones, S. L., Otieno, P., MalecheObimbo, E., Richardson, B., et al. (2009). The detection of cytomegalovirus DNA in maternal plasma is associated with mortality in HIV-1-infected women and their infants. AIDS 23, 117-124. doi: 10.1097/QAD.0b013e32831c8abd

Slyker, J. A., Rowland-Jones, S. L., Dong, T., Reilly, M., Richardson, B., Emery, V. C., et al. (2012). Acute cytomegalovirus infection is associated with increased frequencies of activated and apoptosis-vulnerable T cells in HIV-1-infected infants. J. Virol. 86, 11373-11379. doi: 10.1128/JVI.00790-12

Stevens, D. R., Sawinski, D., Blumberg, E., Galanakis, N., Bloom, R. D., and Trofe-Clark, J. (2015). Increased risk of breakthrough infection among cytomegalovirus donor-positive/recipient-negative kidney transplant recipients receiving lower-dose valganciclovir prophylaxis. Trans. Infect. Dis. 17, 163-173. doi: 10.1111/tid.12349

Tembo, J., Kabwe, M., Chilukutu, L., Chilufya, M., Mwaanza, N., Chabala, C., et al. (2015). Prevalence and risk factors for Betaherpesvirus DNAemia in Children $>3$ Weeks and $<2$ Years of age admitted to a large Referral Hospital in Sub-Saharan Africa. Clin. Infect. Dis. 60, 423-431. doi: 10.1093/cid/ciu853

van der Sande, M. A., Kaye, S., Miles, D. J., Waight, P., Jeffries, D. J., Ojuola, O. O., et al. (2007). Risk factors for and clinical outcome of congenital cytomegalovirus infection in a peri-urban West-African birth cohort. PLoS ONE 2:e492. doi: 10.1371/journal.pone.0000492

Viljoen, J., Tuaillon, E., Nagot, N., Danaviah, S., Peries, M., Padayachee, P., et al. (2015). Cytomegalovirus, and possibly Epstein-Barr virus, shedding in breast milk is associated with HIV-1 transmission by breastfeeding. AIDS 29, 145-153. doi: 10.1097/QAD.0000000000000527

Wang, D., and Fu, T. M. (2014). Progress on human cytomegalovirus vaccines for prevention of congenital infection and disease. Curr. Opin. Virol. 6, 13-23. doi: 10.1016/j.coviro.2014.02.004

Webster, A., Grundy, J. E., Lee, C. A., Emery, V. C., Cook, D. G., Kernoff, P. B., et al. (1989). Cytomegalovirus infection and progression to AIDS. Lancet 2, 681. doi: 10.1016/S0140-6736(89)90928-8

Wohl, D. A., Zeng, D., Stewart, P., Glomb, N., Alcorn, T., Jones, S., et al. (2005). Cytomegalovirus viremia, mortality, and end-organ disease among patients with AIDS receiving potent antiretroviral therapies. J. Acquir. Immune Defic. Syndr. 38, 538-544. doi: 10.1097/01.qai.0000155204.96973.c3

Zhang, X. W., Li, F., Yu, X. W., Shi, X. W., Shi, J., Zhang, J. P., et al. (2007). Physical and intellectual development in children with asymptomatic congenital cytomegalovirus infection: a longitudinal cohort study in Qinba mountain area, China. J. Clin. Virol. 40, 180-185. doi: 10.1016/j.jcv.2007.08.018

Conflict of Interest Statement: The authors declare that the research was conducted in the absence of any commercial or financial relationships that could be construed as a potential conflict of interest.

Copyright (c) 2015 Adland, Klenerman, Goulder and Matthews. This is an openaccess article distributed under the terms of the Creative Commons Attribution License (CC BY). The use, distribution or reproduction in other forums is permitted, provided the original author(s) or licensor are credited and that the original publication in this journal is cited, in accordance with accepted academic practice. No use, distribution or reproduction is permitted which does not comply with these terms. 